\title{
„Krajina a evoluce"? Evolučně-psychologické teorie percepce krajiny
}

\author{
Marco Stella, Karel Stibral \\ Envigogika 2009/IV/2 - Recenzované články/ Reviewed Papers \\ Publikováno/Published 30. 09. 2009 \\ DOI: http://dx.doi.org/10.14712/18023061.41
}

\begin{abstract}
Abstrakt:
Článek se věnuje kritickému zhodnocení evolučně psychologických teorií věnujících se problematice původu lidských estetických preferencí ve vnímání krajiny. Sledujeme zde kořeny těchto úvah $v$ konceptu EEA (Environment of Evolutionary Adaptedness) a rozlišujeme jejich jednotlivé proudy a vývoj - habitat theory, prospect-refuge theory a konečně i vrcholně problematické a populární savanna theory. U poslední jmenované poukazujeme na její problematická místa. Především upozorňujeme na neadekvátní ztotožnění lidského EEA s prostředím pleistocénní Afriky a neproblematické stanovení lidských estetických preferencí jako "orientovaných na savanu". Krom toho, že takový přistup Ize považovat za de facto neevoluční, Ize položit i několik argumentů proti univerzálnosti těchto preferencí z oblasti kulturních dějin. Oproti úzce definovaným a konkrétním představám o evolučně-biologické relevanci preferencí krajin savanového typu stavíme méně známou, ale věrohodnější a obecnější teorii Kaplana a Kaplanové (1989).
\end{abstract}

\section{Klíčová slova:}

Savanna theory, evoluční psychologie, Appleton, estetické vnímání př́rody, Kaplan, habitat selection

\begin{abstract}
:
The article critically evaluates evolutionary-psychological theories of human landscape preference and its aesthetical appreciation. We follow the roots of these thoughts within the EEA concept and their divergent development in separate theoretical trends - habitat theory, prospect-refuge theory and lastly the highly problematic savanna theory. Dealing with the last mentioned, its dubious elements are highlighted. We draw attention to the inadequate connection between human EEA and Pleistocene Africa and the unproblematic determination of human aesthetical preferences as "savanna oriented". Such an attitude is de facto anti-evolutionary and several arguments against it can be given from the field of cultural history. The narrowly defined notions of evolutionarybiological relevance of the preference of savanna-type landscapes are in a strict contrast with other lesser known, yet much more credible and general theory of Kaplan and Kaplan (1989).
\end{abstract}




\section{Key words:}

Savanna theory, evolutionary psychology, Appleton, aesthetic perception of nature, Kaplan, habitat selection 
Je naše vnímání krajiny a to, jak ji hodnotíme evolučně podmíněno? Existuje jakási ideální krajina, která se takř́íajíc líbí všem a cítí se v ní jako doma? Jde o krajinu, ve které žili naši pleistocénní předci? A žije naše mysl stále $v$ jejím zajetí? Jsou výzkumníci, kteří se domnívají, že na tyto otázky i v tak složitém poli, jako jsou otázky kolem krajiny, znají jednoznačnou odpověd'.

$\checkmark$ tomto textu bychom se rádi věnovali možnostem, které nabízí pro vnímání krajiny poznatky z výzkumu založeného na disciplínách spojených s moderní evoluční teorií, at již se jedná o etologii, sociobiologii, či evoluční psychologii. A to především těch, které mají co říci ke vnímání krajiny jako zdroji estetické libosti' ${ }^{1}$. (Orians, 1980; Ulrich, 1983; Ulrich 1986) Zejména v posledních desetiletích či spiše letech vzrostla popularita evolučních vysvětlení, které se pokouší dosud "subjektivní" lidské emoce převést na více "objektivní" bázi, logicky zdůvodnitelnou a doložitelnou empirickým výzkumem. Oblast výzkumu založená na evoluční teorii se také snaží přemostit jistou mezeru či někdy až propast mezi humanitními a př́rodovědnými obory, a atraktivita jejích interpretací je jistě založená i na této interdisciplinaritě. Otázkou zůstává, zda o tento typ "interdisciplinarity", čti nezř́lka jako "loupeživou výpravu na druhou stranu propasti", je nutné a žádoucí usilovat skutečně vždy a za všech okolností. Snaha převést tak komplikovaný diskurs jako je právě problematika krajiny a jejího vnímání na jednoduchý príběh, nota bene vychází-li tato iniciativa od evolučních psychologů, výzkumníků známých jak svými poučnými vhledy do různých oblastí, tak svou alarmující (a často snad i záměrnou) ignorací jiných než evolučně-psychologických rámců, musí nutně budit nikoliv snad nutně podezření, avšak zcela určitě ostražitost. Obzvláště pokud tato oblast bádání, snad nevědomky parodujíc rané darwinisty 19. věku, odkazuje na svou "exaktnost" a "vědeckost" a prítom si vybírá ty jevy, které se jí jaksi hodí do krámu, zatímco onu většinu, která se do krámu naopak nehodí vůbec, taktně zamlčuje.I když jsou tedy evoluční interpretace vnímání krajiny jistě inspirativní a dle motta "na každém šprochu pravdy trochu" na nich skutečně něco bude, je třeba upozornit na to, že jejich platnost je více než omezená.

Jednu z oblastí, kde výzkum spojený s evoluční teorií, resp. evoluční biologií předložil řadu hypotéz, Ize označit jako "evoluční estetiku krajiny". Především jedna z nich, nazývaná obvykle savanna theory, se velmi rozšírila a prakticky dnes již „zlidověla". Tato teorie ( $\mathrm{s}$ oblibou experimentálně dokazovaná ${ }^{2}$ ), $v$ podstatě tvrdí, že člověk $v$ podstatě bezpodmínečně esteticky prefereruje krajiny savanového typu. Vychází se přitom ze zcela správného předpokladu, že naši biologičtí předkové (stejně jako náš druh jako takový), se vyvíjeli ve východoafrické savaně a že i naše momentální fyzická i psychická konstituce nese výrazné otisky tohoto prostředí v podobě adaptací. Zpưsob, jakým se však savanna theory těchto faktů zmocnila, si nicméně zaslouží komentáŕ. Aniž by bylo naším cílem nějaké „vyvrácení" této teorie, rádi bychom poukázali na její někdy nepřesvědčivou argumentaci či diskutabilní obecnou platnost. Tím bychom také chtěli vyplnit určitou mezeru $v$ českém prostředí, kde tato teorie nebyla, pokud je nám známo, kriticky diskutována, a naopak možná až na pár výjimek (např. Librová 1989) ani dostatečně

1 V novověké Evropě se pod estetickou libostí/zalíbením rozumí libost vzniklá na základě vjemu distančních smyslů (zrak a sluch) nezávislá na dobru, užitečnosti atp. Říkám-li, že je něco krásného, znamená to, že to vzbuzuje moji libost bez ohledu na vhodnost či účelnost dotyčného objektu (krásná se mi jeví socha bez jakéhokoliv vztahu k nějakému účelu, a naopak, z funkčnosti nevyplývá krása: představte si zcela funkční a potřebnou žumpu, kanalizaci, vnitřnosti...). Tato libost není primárně libostí smyslů (vjem určité barvy není vjem krásy) a má kontemplativní povahu, tj. je dále rozvíjen reflexí našich smyslových vjemů, což např. jakkoliv "krásný" zážitek vůně neumožňuje (zkuste čichat vůni byt' jen pět minut). Tyto charakteristiky, jak patrno, jsou bohužel $v$ př́krém rozporu snahy biologie převést krásu na nějakou vlastnost týkající se užitečnosti, adaptace atp. Obdobně typické pro novověk je $v$ podstatě odmítání jednoduché převoditelnosti krásy na proporcionalitu, symetričnost atp. - opět ve značném rozporu se snažením současných biologů.

2 Pro přehled literatury viz především Eckhart, V., Grammer, K (eds.). 2003 Evolutionary Aesthetics. Heidelberg: Springer 2003. K nalezení zde je nejen rozsáhlý přehled týkající se "evoluční estetiky krajiny" (Ruso, Renninger, Atzwanger, 2003, s. 279-294), ale i mnoha dalších odvětví evoluční estetiky. 
využita v odborném kontextu. Dnes patří tato teorie do téměř automatického arzenálu diskusí nad naším estetickým vnímáním krajiny i v popularizačních textech (např. Koucká 2006), aniž by nad tímto konceptem proběhla hlubší diskuse. V neposlední řadě bychom také rádi upozornili na to, že v rámci samotné evoluční teorie se jedná pouze o jednu hypotézu, a že bychom zde mohli najít daleko širší a zajímavé pole rưzných hypotéz a výzkumů. A to hypotéz, které by možná lépe splňovaly naše požadavky na teorii, která by se prípadně mohla uplatnit i ve zkoumání našeho vztahu k životnímu prostředí a krajině, a samozřejmě i v jejich ochraně.

\section{Evoluční psychologie jako samostatná disciplína}

Pokud mluvíme o oborech spojených s moderním výkladem evoluční teorie a specificky o "savanna theory", pak bychom měli nejdřive představit kontext jejího vzniku. Tato teorie vznikla na půdě tzv. evoluční psychologie, oboru, která zasahuje (někteří by řekli - postihuje) jak oblast humanitně-společenskovědní, tak i př́rodovědnou, resp. biologickou. Pro pochopení evolučních interpretací krajiny je potřeba se proto nejdřive zastavit u jejího teoretického pozadí. Věnujme tedy delší úvod i samotné evoluční psychologii, která opět byla v českém kontextu představena minimálně (Barret, Dunbar, Lycett, 2007; Michel, Mooreová 1999), a to i s ohledem na její popularitu a také vzrůstající autoritu $v$ některých oblastech lidského poznání.

Snahy o vytvoření přírodovědné nauky o duši, jejích kvalitách, mohutnostech a hnutích jsou staré jako disciplína sama³ a nejinak tomu je i s pokusy ji "darwinizovat" víceméně každý z "Darwinových pohrobků" něco o významu darwinismu pro výzkum lidské či zvířecí duše napsal a tato pojednání bezesporu sklízela velkou popularitu. Evoluční psychologie (Evolutionary Psychology, často pouze jako EP) se ale jako samostatná, teoreticky propracovaná a aplikovatelná disciplína etablovala až v 70. - 80. letech 20. století, především zásluhou Johna Toobyho, Johna Bowlbyho, Ledy Cosmidesové, Robina Dunbara, Donalda M. Busse a dalších, jako disciplína na pomezí darwinistické evoluční biologie, psychologie (vývojové, environmentální, okrajově psychoanalýzy), antropologie a jejích subdisciplín, neurověd, teorie her, kognitivních věd atd. Ač je historie jejího pưvodu zajímavá4 ${ }^{4}$ stejně jako její takřka výhradní rozšíření v anglosaské jazykové oblasti (na Starém kontinentu její roli suplovala a částečně i nadále supluje jinak teoreticky založená etologie člověka), nezbývá než odkázat na příslušnou literaturu ${ }^{5}$, nebot́ nás zde zajímá především vlastní "savanna theory". Abychom však pochopili důvody jejího hlubokého zakořenění v evoluční psychologii a z toho vyplývající tvrdošíjnost, s jakou se jí

$3 \mathrm{Na}$ počátku př́rodovědného, resp. fyziologického chápání psychologie (včetně interpretace estetických zážitků) stojí v 19. století zejm. Wilhelm Wundt, Hermann von Helmholz či Gustav Fechner.

4 Spojení evoluční psychologie bylo pravděpodobně poprvé užito americkým biologem Michaelem Ghiselinem v článku publikovaném roku 1973 v Science. Termín sám byl zpopularizován až ve značně rozšírené knize The Adapted Mind: Evolutionary Psychology and The Generation of Culture z r. 1992 od Jerome Barkowa, Ledy Cosmidesové a Johna Toobyho. Od počátku provázely etablování evoluční psychologie často zatrpklé spory se zastánci behaviorální ekologie člověka (human behavioral ecology, HBE) zaměřující se na měření rozdílu $v$ reprodukčním úspěchu mezi jedinci $v$ závislosti na různých behaviorálních strategiích a využívající metody a postupy obdobných studií na zvířatech. Na druhé straně je evoluční psychologie značně paralelní Wilsonem založené sociobiologii (Wilson, $\mathrm{E}$. O.: Sociobiology: The New Synthesis, 1975), přičemž Wilson sám neviděl mezi oběma disciplínami podstatného rozdílu. Českému čtenáři mưžeme doporučit učebnici pokoušející se sjednotit přístup jak EP tak HBE: Barrett, Dunbar, Lycett, 2007.

${ }_{5}^{5}$ Pro stručné přehledy dějin oboru a také kritické poznámky k jeho vývoji viz například Caton, 2007; Panksepp, Panksepp, 2000; Ingold, 2000. Obecně Ize říci, že dějiny evoluční psychologie, i přes jistou frapantnost a občas i skandálnost této disciplíny jsou v podstatě polem neoraným. Také ku škodě evolučních psychologů samotných. 
mnozí její proponenti drží, nevyhneme se stručnému zopakování nejobecnějších postulátů evoluční psychologie, které tvoří její základy.

Celkem vzato tradičně a nijak překvapivě evoluční psychologie tvrdí, že člověk se nerodí jako tabula rasa a některé jeho psychické vlastnosti, sklony, kognitivní a emoční ustrojení jsou do jisté míry vrozené a dědičné. Především ale, a tím se již liší od některých dalších oblastí, evoluční psychologie zdůrazňuje, že v těchto prípadech (vrozeného, dědičného chování a aspektů kognice) se jedná o vlastnosti vzniklé v rámci lidské evoluce, které mají značnou stabilitu (tj. uvnitř druhu se př́liš nemění v čase ani prostoru) a Ize je vykládat pouze s přihlédnutím k evolučnímu kontextu jejich vzniku. Funkci (či naopak malfunkci) daného aspektu psychiky nebo chování tak Ize posuzovat pouze s ohledem na evoluční historii. To pak často vede ke spekulativnímu charakteru některých evolučněpsychologických závěrů. S trochou skepse by se dalo hovořit i o jakési "evoluční mytologii". Typ otázek, na které evoluční psychologie hledá odpovědi, totiž nabírá často až mytologický nádech - kdo jsme, jací jsme, kam patříme, či dokonce jak si správně vybrat partnera. Při značné míře nadsázky (a v úctě $k$ těm, kteří s evolučními vysvětleními nakládají rozumně a zodpovědně) Ize vidět úspěch a především popularitu evoluční psychologie právě v tom, že "umí" (přiznejme, občas poněkud neskromně) poskytnout odpovědi na tyto velké otázky lidstva a člověka. Zda jsou tyto odpovědi uspokojivé či ve shodě s empirií, zde rozebírat nechceme ani nemůžeme. Na rozdíl od mandibuly či holenní kosti psychickou či kognitivní funkci nemůže z principu vykopat ani ten nejschopnější paleontolog, bohužel.

Evoluční psychologie tedy zkoumá ultimátní příčiny daného chování či psychické vlastnosti, ptá se po jejich funkci ${ }^{6}$ z hlediska evoluce - táže se, k čemu daná vlastnost sloužila v evoluční historii a také proč, za jakých podmínek a kdy vznikla a již výrazně méně se zajímá o reálný průběh nějakého behaviorálního či kognitivního projevu. Evoluční psychologie hojně pracuje s konceptem modularity mysli (modularity of mind) - lidská psychika je vybavena určitou sadou „nástrojư" vzniklých během evolučního vývoje (tzn. že některé z těchto nástrojů jsou prastaré a sdílí je množství organismů, jiné naopak mohou být specificky lidské a evolučně novější). Mysl tak připomíná švýcarský nožík, užitečnou věc plnou nejrůznějších nástrojů, které se dají použít k různým věcem. Zatímco s „vývrtkou" Ize dělat jen jednu věc, tj. dobývat se do láhve, například "nůž" nebo „pilka" jsou nástroje všestranné a použitelné na mnoho různých věcí. A zatímco s pomocí švýcarského nožíku můžeme, řekněme, postavit nouzový přístřešek, na stavbu mrakodrapu nám již rozhodně stačit nebude. Podobně i lidská mysl má určité limity a mantinely, v nichž se pohybuje. Z výše řečeného vyplývá skutečnost, že se evoluční psychologie tradičně vymezuje vưči behaviorální ekologii (BE, případně Human behavioral ecology, HBE), která se zabývá především optimálností daného chování v prostředí a přizpưsobivostí organismů. Evoluční psychologie právě naopak, s poukazem na evoluční minulost organismu a jeho behaviorálně-kognitivní rigiditu, ráda ukazuje na různé nedokonalosti a „selhání" dané adaptace v prostředí. Přibližně dvě poslední desetiletí jsou nicméně poznamenány snahou o syntézu obou přístupů a hranice, kdysi držené s takřka bojovým nasazením, se již dávno na mnoha místech prolomily.

\footnotetext{
${ }^{6}$ Tím se výrazněji odchyluje od jiného směru behaviorálně-kognitivního výzkumu, tj. etologie - ta totiž primárně zkoumá primárně "formu", je primárně morfologií chování a výzkum funkce jako takové je až druhotný. Vlastně i celý přistup je u etologie opačný - vychází od jednotlivých, konkrétních pečlivých pozorování chování a dále postupuje induktivně, tj. obecnější, evoluční rámec hraje vlastně až sekundární roli, zatímco evoluční psychologie považuje evoluční funkci nějakého chování za předem jasnou a danou a z pozice tohoto obecného předpokladu, tj. že každé chování či psychická vlastnost má (měla) evoluční roli, pak deduktivně vysvětluje jednotlivé typy projevů. To, jak skutečně konkrétní behaviorální projev vypadá, evoluční psychologii vlastně vưbec nemusí zajímat a ve skutečnosti také často vůbec nezajímá.
} 


\section{Co je to vlastně „přirozené prostředí" člověka?}

Můžeme říci, že evoluční psychologie se soustřed'uje především na vnitrodruhové prostředí, tedy na interakce uvnitř našeho druhu (to je vzhledem k sociálnímu charakteru člověka více než logické). Evolučně-psychologickému výzkumu tak dominují především různá "sexy" témata jako sexualita, socialita, vztah rodiče a potomka, reprodukční strategie a tak dále. Prostředí mimodruhové, tj. interakce člověka s jinými objekty než lidmi, s tím co nazýváme "prírodou" či "krajinou" atp., zůstává do jisté míry upozaděno. Sem patří například výzkum fobií či naopak příchylnosti k nejrůznějším př́rodninám, a konečně také výzkumy týkající se preference habitatu a krajiny. Ačkoliv jsou tato témata výrazně méně sexy, i nejzarytější a nejvášnivější výzkumník sexuality musí uznat, že jeho objekt pravděpodobně pěstovat sex nebude, pokud se bude nacházet ve vyloženě nevhodném prostředí. Výběr habitatu (habitat selection) totiž hraje pro každý organismus (schopný samostatného pohybu) zcela klíčovou roli.

Prostředí, či úžeji habitat rozhoduje o úspěšnosti získávání zdrojů, ochrany před biotickými i biotickými faktory atd. Prostředí rozhoduje o úspěšnosti prežití a reprodukce organismu stejně jako stav organismu samotného. Také je jasné, že různé organismy jsou rủzně tolerantní vưči podmínkám prostředí - některé jsou se svým habitatem takřka fatálně svázány (motýli reprodukčně vázaní na jeden či několik málo druhů rostlin), jiné naopak k němu mají vlažnější vztah (hezkým příkladem by byl kosmopolitně rozšířený potkan nebo člověk). Lze tedy předpokládat, že organismy budou disponovat takovými kognitivními mechanismy, které jim umožní najít a obydlet relevantní prostředí (habitat). Tomuto tématu se budeme věnovat níže.

Ještě předtím však nelze nezmínit jeden z dalších významů slova "prostředí", který v rámci behaviorálních věd nese. Předem je třeba předeslat, že problém, který spatřujeme se savanna theory, spočívá právě $v$ jakémsi pomatení těchto speciálních významů „prostředí" v rámci evoluční teorie. Máme na mysli pro evoluční biologii a psychologii důležitý pojem Environment of Evolutionary Adaptedness (prostředí evoluční adaptovanosti, EEA), se kterým přišel již zmíněný otec evoluční psychologie, psychiatr, psycholog a psychoanalytik John Bowlby. Ten je znám především svou teorií attachmentu ${ }^{7}$ (zabýval se především vývojovou psychologií a vazbou lidského mláděte na matku), nicméně teorie EEA, která je původně její integrální součástí, ji svým významem snad zastiňuje. Bowlby o EEA pưvodně uvažoval $v$ rámci své teorie attachmentu - různé typy reakcí dítěte na matku dávají smysl pouze z evolučního hlediska, tj. jsou adaptivní pouze $\checkmark$ rámci původních přirozených lidských societ. Je tedy více než patrné, že Bowlby o EEA uvažoval pouze jako o záležitosti vnitrodruhového prostředí - komplikované geneze vztahu matky (př́íp. jiné o dítě pečující osoby) a jejího potomka. Koncept EEA se nicméně dočkal aplikace nejen na oblast psychiky, ale také na fyzické vlastnosti a jak uvidíme, dokonce i na vztah k mimodruhovému prostředí.

EEA je dnes definováno jako souhrn všech selekčních tlaků, které vedly ke vzniku určité adaptace či jako ty aspekty prostředí, které jsou nutné k tomu, aby se daná adaptace správně vyvíjela a fungovala. (Blíže viz např. Barret, Dunbar, Lycett 2007) Nejde tedy o nějaký konkrétní bod $v$ čase či prostoru. Někteří si tuto definici nikoliv zcela správně vyložili tak, že jde o prostředí, v jakém se daný organismus vyvíjel po většinu své evoluční historie. EEA tedy zároveň vystupuje jako určitý limitujíć faktor dalšího vývoje. Čím více se aktuální prostředí podobá EEA, tím větší reprodukční výhody adaptace organismu přináší, čím méně, tím více je organismus znevýhodněn. (Např. Symons 1992)

7 Teorie attachmentu je evolučně-psychologický rámec, který slouží k vysvětlování mezilidských vztahů z charakteru raného vztahu matky a dítěte, navíc ohledem na možný adaptivní význam různých typů těchto vazeb (attachment). S trochou nadsázky ji Ize považovat za velmi elegantní a propracovanou syntézu „Freuda" S „Lorenzem". Viz Bowlby, 1969-1982. 
Od 70. let evoluční psychologové koncept EEA aplikují na širokou škálu psychických a kognitivních vlastností - takřka všechny kvality lidské mysli musí být podle nich nutně adaptací na prostředí pleistocénní (1,8 milionu let až 12 tisíc let před současností) východní Afriky, kde se rod Homo prokazatelně přibližně poslední milion a půl let vyvíjel. Zde se přibližně před 130 - 200 tisíci lety vyvinul i jediný recentní druh tohoto rodu, my, tj. Homo sapiens sapiens. Africkou kolébku opustil až před cca 100 tisíci lety a své životní návyky, které jej po celou dobu jeho existence provázely, tj. lovectví a sběračství (a spolu s tím i značnou část svého životního prostředí) začal dramaticky měnit až před nedávnem přibližně před 10 tisíci lety (tj. nepatrný zlomek času, po který náš druh i rod existuje).

Evoluční psychologie, jak již bylo řečeno, vychází z toho, že funkce a adaptovanost jednotlivých složek lidské psychiky nelze odvozovat z jejich stávající funkce (nebo naopak malfunkce), ale právě pouze z pleistocénního prostředí, zcela ztotožněného s naším EEA. ${ }^{8}$ V zásadě pouze zde evoluční psychologové hledají a nacházejí příčiny, které ovlivňují i naše aktuální chování. Oněch posledních 10 tisíc let radikálních a hlubokých změn našeho životního stylu je podle nich málo, aby se naše v pleistocénu vyselektované vrozené adaptace mysli jakkoliv změnily (často v těchto souvislostech slýcháme 0 "lidech doby kamenné řítících se dvoustovkou po šestiproudé dálnici" atp.). Celá řada toho, co dnes děláme, cítíme či jak o věcech uvažujeme, mohla tedy být adaptivní u lovcủ a sběračů v pleistocénní Africe, ovšem jimi vyrobený "software" nesený námi samotnými mưže být vyloženě maladaptivní, resp. pokud cokoliv v současnosti adaptivní je (má pozitivní vliv na fitness) je to pouze a jenom proto, že koresponduje s EEA. Proto i když dnes hadi a pavouci představují příčinu byt́ jen zcela nepatrného zlomku z počtu všech úmrtí, na rozdíl třeba od automobilů, střelných zbraní a fastfoodů, existují fobie a averze právě jen vưči nim a nikoliv vưči kamionům, samopalům a smaženkám.

Vrat́me se nicméně na skok ke zmíněnému prvnímu významu prostředí. Výběr prostředí (habitatu) byl v naší evoluční minulosti bezesporu mnohem důležitější než dnes, kdy své okolí pomocí rưzných kulturních výdobytků k tomu určených aktivně a dramaticky měníme, především v přibližně posledních 10 tisíci letech. Pro lovce a sběrače, recentní $\mathrm{i}$ minulé (tj. naše předky), je výběr prostředí, nebo chceme-li dát tomuto neutrálnímu výrazu tradičnější rozměr, krajiny důležitý z mnoha hledisek.

Za všechny vlivy, které ovlivňovaly výběr krajiny, zmiňme její prostupnost (možnost pohybu v krajině), možnosti ochrany před nepřáteli (vlastního či jiného druhu) a počasím, výběr a množství zdrojů jako potravy, vody, paliva atd. Dalším, snad méně akcentovaným dưležitým aspektem, je ekologická stabilita prostředí. Člověk je typický K-stratég9: vyznačuje se větší velikostí těla, dlouhou střední délkou života a také velmi intenzivní a dlouhou péčí o malý počet dlouho dospívajících a "drahých" mlád’at, která mají ovšem relativně vysokou šanci přežít a rozmnožit se (opačně se chovají r-stratégové - jako př́klady si můžeme představit například slona a hraboše). Z těchto důvodů K-stratégové obývají ekologicky stabilní prostředí $v$ počtech stabilně se držících kolem $K$, tedy nosné kapacity prostředí. Stabilita, jejímž projevem je mj. i víceméně stálé množství zdrojů, je totiž nezbytným předpokladem, aby bylo možné a výhodné odchovávat právě malý počet dlouho dospívajících a velmi drahých mlád’at.

\section{Jak vypadá ideální krajina podle evolučních psychologů?}

V rámci evoluční logiky pak dává smysl, že ti, kteří si správné prostředí vybrat neuměli, bud' zahynuli, nebo nevyvedli žádné potomky. Náročnost podobného úkonu,

\footnotetext{
${ }^{8}$ Cosmides, Tooby, 1987; Symons, 1989; Symons, 1990. Don Symons je bezesporu nejurputnějším bojovníkem za pravdivost konceptu EEA v rámci evoluční antropologie a psychologie.

9 Kořeny teorie $\mathrm{K}$ a $\mathrm{r}$ selekce nalezneme v MacArthur, Wilson, 1967. Stala se nedílnou součástí ekologie a ochranářské biologie.
} 
tj. najít dobré místo k táboření, si vyzkoušel každý, kdo byl někdy „na čundru". Abychom získali lepší představu o životě lovcư a sběračů, můžeme si představit, že pro ně takový čundr trval celý život, přičemž nebylo možné zajít si do hospody či samoobsluhy do nejbližší vesnice a v táborovém prostředí se také odehrávaly všechny veselé i smutné věci, které patří $\mathrm{k}$ lidskému životu. Vybrat si to správné místo mohlo často představovat rozdíl mezi životem a smrtí.

Proto evoluční psychologie očekává, že právě kognitivní a emoční reakce na prostředí byly pod extrémně silným selekčním tlakem. Lze tedy očekávat také značnou shodu $v$ těchto reakcích mezi všemi recentními lidmi (jsme totiž potomky těch, kteří si uměli vybrat a rozmnožili se, a jelikož všichni pocházíme z Afriky, vkus našich předků se musel tvarovat právě na širých pláních a zelených pahorcích afrických).

Tyto emoční reakce, pocity libosti a nelibosti vưči danému prostředí, podle evoluční psychologie fungují jako silné motivátory lidského chování. Naše pocity a behaviorální reakce na prostředí tedy jsou evolučními připomínkami toho, co nám $v$ naší evoluční minulosti pomáhalo najít dobré prostředí pro přežití a rozmnožování.

Prostředí musí bezesporu naplňovat lidské biologické potřeby, a proto přírodní výběr zvýhodňoval ty jedince, kteří se zabydlovali tam, kde tomu tak skutečně bylo. Tak vznikly vrozené preference pro určitý typ krajinných tvarů (i barev v krajině) a daly základ estetickému zalíbení v (určité) krajině. Slovy Jaye Appletona, autora známé "habitat theory" formulované v knize The Experience of Landscape (1975):

...estetické uspokojení zakoušené při pohledu na krajinu vychází ze spontánního vnímání vlastností krajiny, která prostřednictvím svých tvarů, barev, prostorového uspořádání a jejích dalších viditelných atributů působí jako indikátor podmínek prostředí vhodného k přežití, a to at' již skutečně k přežití vhodné jsou či nikoliv. (Appleton, 1975: 69)

Ze specifik lidské situace, tj. kombinace délky reprodukčního cyklu, nároků na potravu, lovecko-sběračského stylu života a relativní zranitelnosti lidského jedince, vyplývá pro člověka nad prostou biologickou potřebu přítomnosti zdrojů v krajině (viz níže) ještě něco navíc - krajina musí poskytovat dobrý rozhled a být přehledná a také prostupná, musí umožňovat výhled, „prospect". Nadto člověk (a samozřejmě i jiné živočišné druhy) má potřebu ochrany, úkrytu, krajina mu musí tedy nabízet úkryt či bezpečné útočiště, "refuge". Tato Appletonova teorie, navazující těsně na habitat theory byla nazvaná, jak asi nepřekvapí, „prospect-refuge theory", vlastně ř́ká jedno - člověk hodnotí pozitivně ty typy krajin, které nabízejí možnosti vidět a nebýt přitom viděn. V evoluci se tedy musely vyvinout pozitivní reakce na krajinu splňující tato kritéria a naopak negativní na ty, kde se není kam schovat a (nebo) jsou nepřehledné a neprostupné.

Nutná je samozřejmě i př́tomnost zdrojů, jak již bylo naznačeno výše. Mezi ty nejzákladnější patří voda. Kde je voda, bývá i zelená vegetace (musí být ovšem prostupná, aby poskytovala „prospect") a kde jsou zelené rostliny, najde se i nějaký ten živočich. Stručně, pro lovce-sběrače prostředí vpravdě ideální.

Výstižně a stručně definoval Eibl-Eibsfeldt (1984) člověka je bytost fytofilní a hydrofilní, která je psychologicky a behaviorálně přitahován k vodě a zeleným rostlinám. Popravdě, právě $v$ těchto bodech se shodují takřka všechny evolučně-psychologické (evolučně-estetické, chceme-li) teorie o tom, co by "správná krajina měla obsahovat". Na konci tohoto textu se ještě k těmto preferencím u různých autorů vrátíme ve formě přehledné tabulky. 


\section{Savanna theory a její problémy z pohledu evoluční biologie}

Z Appletonovy habitat theory a prospect-refuge theory nicméně posléze vyšel Orians (1980) se svou slavnou a neustále traktovanou "savanna theory"10. Stručně shrnuto, touto teorií tvrdí, že moderní lidé mají vrozenou preferenci pro krajiny savanového typu, protože savana odpovídá našemu hypotetickému EEA. Savana byla skutečně biotopem, kde se formoval nejen náš druh, ale i celý rod Homo, proto tato teorie vychází z toho, že kognitivní mechanismy, které našim předkům umožňovaly rozpoznat prostředí, které se $\checkmark$ minulosti osvědčilo, musí být i základem našich současných estetických preferencí vůči krajině.

Ale: prosíme čtenáře, aby si povšiml, že tato teorie zcela svévolně zaměňuje „prostředí" ve smyslu krajiny a EEA, které ovšem žádným konkrétním prostředím není! Tato teorie se nicméně stala teoretickým základem pro většinu empirických výzkumů zaměřených tímto směrem (např. Syneck, 1998), ale i oporou pro ty, kteří se domnívají, že nám je vrozená především obliba tzv. arkadské, resp. parkové krajiny, které jsou chápané jako jakýsi surogát savany. Jedná se ve všech prípadech o mírně zvlněnou krajinu, kde se stř́́dají otevřené zatravněné plochy s jednotlivými stromy nebo menšími lesíky, v níz se pasou stáda velkých savců (dobytka), nachází se zde i voda (napajedlo) atp.

Savanna theory a z ní odvozované důsledky pro estetické preference krajiny, resp. krajinného rázu, s sebou však nese celou řadu problémů. Předně s ní nekoresponduje celá řada výsledků empirických prací, ukazujících spíše na preferenci krajiny s jistými stopami lidské př́tomnosti jako jsou stavby či pole (Coeterier, 1996, Ruso, Reinninger, Atzwanger, 2003 atp.), které Ize v původní savaně hledat jen stěží (také to nabourává představy o "vrozenosti" nějakých konkrétních preferencí). Druhým, snad ještě větším problémem by bylo to, proč by tak komplexní kognitivní mechanismus pro preferenci prostředí měl vzniknout pouze $v$ rámci jedné epochy (EEA není definováno jako jeden určitý bod $v$ čase a prostoru, jak se někteří zřejmě domnívají) - silné selekční tlaky na preferenci prostředí musely existovat nejen před pleistocénní érou, ale i po ní. A i kdyby skutečně tyto tlaky byly tak silné, že by zcela vytlačily preference předchozí (Ize se domnívat, že prapředkové člověka, šimpanze a gorily byli brachiující lidoopi, a k tomuto způsobu života se nejlépe hodí hustý prales - viz orangutani) ${ }^{11}$, nevysvětluje to jednu věc. Za předpokladu, že by u všech lidí tehdy žijících měli být tyto preference uniformní (ostatně to evoluční psychologové očekávají i u dnešních populací) a přednastavené na savanu, jak je možné, že z Afriky vůbec někdo odešel?

Emoční a kognitivní reakce na krajinu by z hlediska evoluční logiky měly reflektovat její relevanci z hlediska přežití a reprodukce. Proč se tedy lidé začali masově množit právě až mimo Afriku a především mimo africké savany? Pokud je fixace na krajinu savany tak silná a vrozená, jak tvrdí savanna theory, museli by ti, kteř́ z Afriky odešli, bud' být jacísi podivní mutanti, kterým se v savaně nelíbilo, nebo se jejich preference "cestou" postupně

\footnotetext{
10 Orians svoji teorii inovoval v textu Orians, Heerwagen, 1992. Zde hovoří mj. o čtyřech základních elementech preferencí v krajině: prospect-refuge, fytofilii, hydrofilii a zoofilii.

11 Obliba vody u člověka dala zase naopak vzniknout tzv. aquatic ape hypothesis (AAH) Alistera Hardyho (1960), který upozornil na některé shody mezi člověkem a vodními ptáky a savci. Přechodná perioda vývoje člověka ve vodním, resp. přímořském, prostředí by podle této teorie jednak vysvětlovala některé fyziologické zvláštnosti a odlišnosti od jiných primátů, jako směr ochlupení a jeho ztráta na většině těla, bipedalismus, postavení nosu, schopnost vědomě zadržet dech atp. $\checkmark$ neposlední řadě by tato teorie vysvětlovala nijak zvlášt́ pobytem $v$ savaně selektovanou oblibu pobytu ve vodě, oblibu širých ploch moře atp. Tato teorie či hypotéza byla pak do širšího povědomí rozšířena především díky známé knize Nahá opice Desmonda Morrise (The Naked Ape, 1967). Z toho je patrné, že evoluční vysvětlení mají (kromě své mytologičnosti) ještě jeden aspekt, který je předurčuje $k$ oblibě a popularitě - jejich prostřednictvím nejen že Ize odvysvětlit takřka cokoliv („člověk evolučně uvázl ve vysychající savaně"), ale stejně dobrý smysl může dávat i výrok zcela tomu zcela opačný („člověk evolučně uvázl v mělké vodě").
} 
měnily (at́ už jakýmkoli způsobem). Savanna theory pak popírá sama sebe hned dvakrát pokud je člověku vrozená preference krajiny savanového typu a tato preference navíc odráží její biologickou relevanci, nevysvětluje to fakt, proč se lidé, technologicky ani biologicky nijak podstatně rozdílní od obyvatel savany, rozšírili tak kosmopolitně. A pokud se tedy preference krajin nějakým způsobem mění (at' již ve smyslu nějaké hypotetické mutace ovlivňující opět hypotetické a takřka jistě neexistující „geny pro preferenci krajiny", nebo ve smyslu prostého učení během ontogeneze), nelze očekávat onu uniformitu, jakou se zastánci savanna theory domnívají svými experimenty dokazovat.

\section{Opravdu se líbí lidem savana? Otázky z oblasti kultury a umění}

S tím souvisí i další námitky vưči zdánlivé preferenci krajiny arkadského typu, ze savanovitého biotopu odvozené. U řady evolučních psychologů je časté odvolávání se na umělecká díla jako na důkazy určitých domněle vrozených a uniformních preferencí (od poměru šířky pasu a boků u nejrůznějších nahotinek až po krajinomalbu), ovšem vpravdě jen těch, které se jim "hodí do krámu". Není totiž nijak složité právě ve sféře umění ukázat, že žádná jednotná preference krajiny savanového typu prostě neexistuje. Předpoklad, že preference krajiny je do jisté míry vrozená a mezi lidmi se neliší, by se projevil ostatně právě $v$ umění. Nicméně pokud má savanna theory pravdu a "ž̌ivot v savaně" ovlivňuje naši kognici a emoce dnes stále stejným způsobem jako v pleistocénní minulosti, kde se pak vzala záliba čínské, mezoamerické či novověké evropské kultury v horách? Jak vysvětlit obdiv ke kráse ledovcư? Proč během značné části kulturního vývoje Evropy bylo cílem krajinu pokud možno geometrizovat $v$ podobě renesančních i francouzských parků, nebo alespoň pravidelných polí a řad stromů? A něco takového, jako anglický park, který teprve splňoval naše domnělé "savanní preference", se vyvinulo teprve ve století osmnáctém? ${ }^{12}$ A když už jsme u arkadské krajiny - ideál této krajiny byl poměrně přesně definován v renesanční poezii na samém počátku 16. století (Sannazzaro, 1966) a navazoval na krajiny líčené v antické bukolické a pastorální poezii - proč do definice této krajiny patří i antické ruiny a schůdné hory na obzoru, porostlé borovicemi a cypřišemi? Jak tyto součásti přímo přispívají k přežití v krajině?

Ostatně, chceme-li se zabývat vůbec nějakými kognitivními mechanismy pro krajinu či krajiny: za zmínku stojí, že v řecké antice třeba ani nenalezneme žádnou zálibu v krajině, ani termín pro ni, ani žádné zobrazení či definování nějakých libých krajin. Najdeme jen často zobrazované preferované místo - locus amoenus - kde by měla být voda, strom či hájek, tráva a zpívající ptáčci (Lorentz, 1935). Sám termín pro krajinu vznikl v evropské kultuře až v renesanci, jako pojem pro scenérie v pozadí obrazu (Andrews, 1999, s. 28-30), nikoliv pro krajinu "skutečnou". Neradi to zmiňujeme, ale bohužel se jako jedno z vysvětlení jisté nedomyšlenosti teorie savany nabízí i její anglocentričnost a nevalný historický záběr - zdánlivě na objektivních faktech založená teorie vykazuje silné znaky kulturních preferencí prostředí, ve kterém vznikla.

\footnotetext{
12 Je dobré si připomenout, že většina evolučních psychologů pochází z anglosaské jazykové oblasti a každý, kdo viděl anglický či krajinářský park musí uznat, že jistá podobnost se savanou (alespoň se savanou v době deštú) tu je. Anglické parky ale jsou vlastní jen určitému okruhu, nejsou zdaleka po celém světě a otázkou zůstává, zda se savanna theory ze značné části nezakládá na kulturní projekci typu "co se líbí nám, se pravděpodobně bude líbit i všem ostatním". Tj. je možné se ptát, zda ideál krajiny není pro badatele $z$ anglosaského kulturního okruhu primárně anglický park a tomu je teprve sekundárně nalezen jakžtakž odpovídající protějšek ve volné přírodě. Je i otázkou, zda i domnělá preference toho, co bychom označili jako "arkadská krajina" nevyplývá spíše ze smyslu (pokud přijmeme možnost vrozenosti nějaké obdobné preference) pouze pro určitý typ místa, které nám např. popisuje již antika. Arkadská krajina i savana $v$ období deštú je pak $v$ podstatě určitou extenzí takového místa doplněná o antické ruiny a horizont.
} 
Otázkou také zůstává, jak dalece je nám opravdu tato preference pro určitý typ krajiny vrozena a vůbec jak jsou představy o krajině na ní založeny. Podíváme-li se nejen na stáŕí tohoto konceptu ve vlastní kultuře, ale také když se podíváme na vztah ke krajině u malých dětí. Je evidentní, že velmi malé děti se o krajinu v podstatě nezajímají a jaksi jí „"nevnímají", stejně jako prostor vnímají značně odlišně od našich zkušeností. Aniž bychom chtěli obhajovat nejrůznější rekapitulační teorie, děti „vidí" spíše to, co "staré" civilizace jednotlivý význačný strom, jednotlivý květ či zvíře, místo u vody, ale nikoliv celek. Tomu také odpovídají dětské kresby, kde se krajina objevuje jako téma až značně později, v podstatě až ve školním věku - menší děti ji (obdobně jako "staré" umění) spíše symbolicky naznačují stromem, trávníkem atp.

\section{Můžeme nabídnout vůbec nějaké „původní" preference?}

Je zjevné, že tak reduktivní teorie jako je "savanna theory" (a vlastně i koncept lidské EEA v podání některých evolučních psychologů) nemůže přes svou popularitu zcela obstát. Pokud nějaké takovéto kognitivní mechanismy určené k hodnocení krajiny z hlediska naplňování biologických potřeb existují, musí působit na mnohem obecnější úrovni. Když se na to, co nám koncept lidské EEA vlastně říká, podíváme střízlivě, nalezneme v zásadě následující: člověk je zcela fatálně spjat se svým vnitrodruhovým a mimodruhovým prostředím typickým pro pleistocénní Afriku a jakékoliv odchýlení od tohoto standardu nutně snižuje jeho reprodukční úspěch. To však až příliš málo koresponduje s do očí bijící skutečností, že člověk je kosmopolitně rozšířen a je schopen žít v bezpočtu různých uspořádání society, stejně jako v nejrůznějších typech krajin. Je skutečně člověk tak závislý na svém "původním", "přírodním" prostředí? Pokud by příslušné hypotetické kognitivně-estetické mechanismy byly tak striktní a uniformní, jak by vůbec bylo možné, že náš druh osídlil planetu takřka od pólu k pólu? Ačkoliv je tedy koncept EEA jedním ze základních postulátů evoluční psychologie, sám o sobě adaptivní evoluci v zásadě vylučuje.

V této souvislosti je na místě zmínit méně známou teorii, která je konkurenční k EEA - je jí koncept adaptivně relevantního prostředí (Adaptively relevant environments, ARE) (Irons, 1998). Koncept EEA, jak již bylo řečeno, tvrdí, že čím je současné prostředí podobnější tomu ancenstrálnímu, tím větší reprodukční výhody příslušná adaptace poskytuje a naopak v novém prostředí je vysoce pravděpodobné, že adaptivní výhodu poskytovat nebudou, mohou se stát vysloveně maladaptivními. ARE naopak přichází s tím, že takto klíčových je jen několik zásadních rysů prostředí - je zřejmé, že člověk se takříkajíc skládá z mnoha různých adaptací, které vždy korespondují jen s určitou částí prostředí. Proto když se prostředí změní, postihne tato změna jen některé adaptace (negativně, ale i pozitivně, jimi poskytovaná reprodukční výhoda se může $v$ novém prostředí o to více zúročit!) a celková úspěšnost organismu v daném prostředí se tak může i zvýšit, zatímco u koncepce EEA může de facto jen klesat.

Nelze popřít, že celá řada organismů je skutečně se svým specifickým prostředím svázána. Ovšem důsledná aplikace koncepce EEA by evoluční psychologii vzala epiteton „evoluční". V jistém ohledu se EEA dokonce blíźí koncepci umweltu známého estonského vitalistického antidarwinisty barona Jakoba von Uexkülla (1864-1944). Umweltem tento zástupce tradiční německé biologie počátku 20. století chápal žitý svět každého organismu, který organismus nemưže žádným zpưsobem překročit a do kterého je svým tělem a smysly tak zapasován, zapuštěn, že jakákoliv změna prostředí pro organismus může být fatální13. Možnost evoluční změny pak nepřipadá v úvahu. Organismus je do svého

\footnotetext{
13 Např. Uexküll, 1920, s. 216 a násl. Jakob von Uexküll patří k osobnostem, které jsou v dějinách biologie neprávem opomíjené, pravděpodobně kvůli svému antidarwinismu. Jeho rozsáhlé dílo výrazně přispělo ke vzniku a rozvoji ekologie (Woltereck, Thienemann), etologie (Lorenz), systémové teorie (Bertalanffy) a dalších vědních odvětví. Viz též Stella, Kleisner, 2006.
} 
prostředí zapuštěn bud' zcela dokonale, nebo vůbec - zahyne. Jakákoliv graduální změna prostředí, která by vedla ke změně umweltu a posléze i anatomie a morfologie organismu není v rámci Uexküllovy vůbec možná. Do důsledku vzato, podobně statická je i koncepce EEA aplikovaná na člověka.

Vrat́me se však k výše zmíněné evolučně-psychologické představě mysli jako švýcarského nožíku obsahujícího velké množství často velmi specializovaných nástrojů. Aplikováno na koncepci "savanna theory", existuje celá řada jemných specifických kognitivních mechanismů přesně nastavených na určité charakteristiky krajiny - od elevace terénu přes hustotu vegetace a její strukturu až dokonce pro konkrétní tvar stromů (sic!; ve všech zmíněných př́padech jde o konkrétní výzkumy provedené pod vlivem savanna theory ${ }^{14}$ ). EEA tedy má zahrnovat velké množství rưzných velmi úzce vymezených aspektů prostředí. Koncepce stojící za ARE naopak (ve shodě například s humánní etologií Lorenze a Eibl-Eibesfeldta) postuluje existenci pouze malého množství velmi obecných kognitivních vodítek pro vnímání krajiny. Domníváme se, že pro kosmopolitně rozšířeného generalistu, jakým je Homo sapiens, je přiléhavá spíše druhá ze zmíněných variant.

Koncept ARE je tedy o řád obecnější než EEA a umožňuje uvažovat skutečně evolučně. Podobně i v rámci biopsychologických vysvětlení estetických hodnocení krajiny je nezbytné hledat obecnější a s empirií slučitelnější teorii, která stanovuje určité obecné charakteristiky esteticky pozitivně hodnocené krajiny, které korespondují s lidskými specifiky. Lidská specifika ve své teorii zohlednil již Appleton (viz výše), nicméně dále v tomto směru pokročili Stephen a Rachel Kaplanovi (Kaplan, 1987; Kaplan, Kaplan, 1989), jejichž koncept "prediction of preference framework" sice do biopsychologických teorií často řazen nebývá, nicméně Ize jej dobře s evolučně-biologickými a evolučněpsychologickými teoriemi uvést $v$ soulad (ostatně sami autoři se přiklánějí k evolučním interpretacím $\left.{ }^{15}\right)$. Přitom se domníváme, že zohledňuje jednu bytostně lidskou vlastnost, která v našem vztahu k prostředí (krajině) hraje důležitou roli. Kaplanovi člověka definují jako knowledge-seeking a knowledge-using organism. K tomu, aby člověk, Ihostejno zda lovec a sběrač či řekněme soudobý turista, mohl v nějaké krajině pobývat a vyrovnat se s ní, musí ji nejprve poznat a průběžně dále explorovat, krajina k němu musí „promlouvat" a člověk její řeči musí "rozumět". Proto by měly být preferovány takové krajiny, které umožňují exploraci a zároveň jsou dostatečně přehledné tak, aby nedošlo ke ztrátě orientace. Na základě svých výzkumů určili 4 kritéria, které podle výše zmíněného klíče (na základě dlouhodobých a krátkodobých možností explorace a porozumění) ovlivňují hodnocení krajiny. Jde o komplexitu, charakterizovanou jako počet nezávislých prvků na scéně - zatímco obilný lán má nízkou komplexitu, primární prales naopak vysokou. Tomu odpovídá i jejich estetické hodnocení. Na první pohled nám komplexita napoví, jaké jsou možnosti explorace $v$ dané krajině. Dalším kritériem pak je spojitost (jednota) krajiny - ta charakterizuje počet a uspořádanost opakujících se prvků v krajině a vypovídá o naší schopnosti se v krajině rychle zorientovat a "pochopit" ji. Dále Kaplanovi hovoří o čitelnosti (identifikovatelnosti) krajiny - ta odpovídá přibližně distribuci prvků ve třetí dimenzi a odpovídá tomu, zda budeme schopni se v krajině zorientovat a najít např́klad cestu zpět, pokud se vydáme hlouběji do krajiny. A konečně čtvrtou charakteristikou nazvanou poněkud mysticky (oprávněně však) tajemství. Ta vypovídá o tom, zda nám krajina jakoby nedává sama sebe zadarmo, zda ji beze zbytku nemưžeme "přečíst", že nám do budoucna dává příslib další explorace. Uzavřené horské údolí, kde známe každý kámen, tajemné není, krajina s řekou vinoucí se za horizont, či údolí ztrácející se v zamlžených horách naopak je.

\footnotetext{
${ }^{14}$ Pro přehledy těchto výzkumů viz Summit, Sommer, 1999; Balling, 1982; Ulrich, 1986.

15 Viz např́klad Kaplanův text $v$ dnes již klasickém evolučně-psychologickém kompendiu Adapted Mind: Kaplan, 1992.
} 
Celá teorie je výrazně promyšlenější, než je prezentováno zde, a navíc je dobře empiricky podložená (Kaplanovi se věnují vylepšování svého konceptu již několik desetiletí) a vychází z ní řada dalších teorií, z nichž zde zmiňme poměrně oblíbenou teorii biodiverzity (poprvé asi Ehrlich, Ehrlich 1992). Je odvozena z prvního bodu matrice Kaplanových a postuluje, že vysoké estetické hodnocení by měly sklízet ty krajiny, které vynikají vysokou biodiverzitou (vypovídající o vyšší stabilitě prostředí a zaručující možnost čerpat velký objem zdrojů) Ač však tento aspekt vyvolává bezesporu naši pozornost, nevysvětluje vše, napríklad prales budeme považovat za krásný pouze do doby, než se $v$ něm beznadějně ztratíme. Spojitost a členitost jsou zcela nezastupitelné prvky. (Čtenáři si možná povšimli, že ona kritéria nejsou aplikovatelná pouze na krajinu, ale také na předměty a v zásadě i na organismy - značně připomínají některé zákonitosti lidské percepce odhalené gestaltpsychologií.)

Nemělo by smysl prodlužovat výčet dalších biopsychologických teorií - cílem tohoto textu bylo poukázat především na to, že popularita "savanna theory", krom toho, že mytologickým způsobem odpovídá na některé "velké otázky" člověka, není zcela oprávněná a že její jednoduchost a líbivost zastiňují existenci jiných, dưvěryhodnějších teorií.

\section{Shrnutí a závěr}

Jestliže se tedy pokusíme nabídnout nějaký závěr z možností, které nám nabízí evoluční psychologie $k$ objasnění našeho vztahu ke krajině, zejména $k$ našim estetickým preferencím s ní svázaným, pak bychom především varovali před pokusy chápat zjištění EP normativně. Ta nám mohou pomoci se pouze orientovat $v$ hypotetické biologické relevanci určitých typů krajiny, nebo pouze částečně vysvětlit některá estetická hodnocení. Rozhodně nám však nemůžou poskytnout nějakou normu, jak má krajina či zalíbení v ní vypadat, stejně jako neposkytnou vysvětlení, proč se nám co a jak líbí. Varovat bychom měli především před hledáním snadných evolučně-kauzálních vysvětlení, jak je nabízí "savanna theory". Koncept EEA, na kterém savanna theory do značné míry staví, není totiž $\checkmark$ př́ípadě člověka přiléhavý a $v$ zásadě nerespektuje lidská specifika. To je ostatně problém který se u nejrůznějších, za každou cenu "darwinizujících", pojetí vyskytuje až př́liš často. Pokud chceme zkoumat člověka, musíme zohledňovat i to čím se odlišuje, nejen to, co má s ostatními tvory společné. Nelze tvrdit, že člověk je bezezbytku "zajatcem" svého "prírodního" prostředí, jak vlastně tvrdí koncept EEA a "savanna theory". Zvláštnost člověka tkví z velké části právě v jeho zvláštním, „otevřeném" postoji ke svému okolí. Jakákoliv teoretická snaha snažící se člověka o tuto jeho zcela očividnou zvláštnost připravit pak nutně vede $k$ tomu, že tvor, kterého popisuje a zkoumá, přestává být člověkem.

Přírodovědci se na humanitní učence dívají často s notnou dávkou pocitu nadřazenosti, což snad vyplývá i z toho, že jim nezřídka chybí jistá sebekritika a sebereflexe, ve které se naopak humanitní nauky utápí. Prírodní vědec mívá nezrídka dojem, že poznává něco, "objektivně", což je postoj pochybnostmi zmítanému humanitnímu vědci značně cizí. Pokud ale mají vznikat přemostění mezi oběma oblastmi lidského poznání (a my věríme, že ano), nemůže se tak dít tím způsobem, že je „humanitní sféra" převedena na metody, jazyk a redukcionismus věd prírodních. A to platí o oblasti estetiky snad v první řadě.

Přesto bychom, jak snad bylo z našeho textu patrné, nezavrhovali evoluční vysvětlení jednoduše proto, že jsou málo „humanitní", to bychom se dopouštěli obdobného omylu, jen při pohledu z druhé strany pomyslné propasti. Je evidentní, že některá zjištění evoluční psychologie můžeme na rozdíl od "savanna theory" za bernou minci vzít - určitě 
zde bude (také intuitivně cítěná) preference př́tomnosti vody a zelených rostlin ${ }^{16}$. Je však otázkou, zda takto obecná zjištění vůbec mohou nabídnout nějaké zásadní poznatky např. pro krajinnou architekturu či krajinné plánování, stejně jako pro pochopení těch kterých preferencí naší kultury. Tyto dva základní požadavky totiž splňují např. i tak odlišná prostředí jako zcela umělý francouzský park, stejně jako zcela přirozený tropický deštný prales. A i když zahrneme do vrozených preferencí o trochu méně doložitelné potřeby úkrytu a výhledu, stále nám zbývá značná pestrost prostředí (od renesančního parku až po onu savanu a lesostep).

A navíc, můžeme připustit, aby nám takto formulované zákonitosti diktovaly naše estetické zájmy? Máme a vůbec můžeme kvůli nim nějak přehodnotit naše estetické preference současné? Např. zavrhnout estetickou hodnotu vyšších partií Alp či Vysokých Tater oproti krajině Polabí? Budeme-li totiž při obhajobě např. zachování krajinného rázu, resp. ochrany určité krajiny argumentovat pouze přírodovědecky, místo argumentace z oblasti vlastního cítění a také z oblasti humanitních věd, dostaneme se dřive či později do značných rozporů.

\section{Poděkování:}

Tento text je jedním z výstupu projektu č. 2B06126 Národního programu výzkumu II. $V$ jiné verzi a s poněkud jiným vyzněním vyjde též v kolektivní monografii: STELLA, M., STIBRAL, K: 2010. Opravdu máme rádi savanu? aneb Biopsychologická východiska vnímání krajiny. In KLVAČ, P.(ed.) Krajinný ráz. Brno: MU.

${ }^{16}$ Pro přehlednost uvádíme následující tabulku různých hypotéz a jimi zjištěných preferencí krajinných prvků:

\begin{tabular}{|c|c|}
\hline Prítomnost vody & $\begin{array}{l}\text { Orians 1980, Eibl-Eibesfeldt 1984, Ulrich 1981, } \\
\text { Palmer } 1978 \text { atd. Appleton 1975, Orians \& } \\
\text { Heerwagen } 1992\end{array}$ \\
\hline Vysoké stromy/Skupiny stromů & Orians 1980, Appleton 1975 \\
\hline Orientační bod/Vyhlídka & $\begin{array}{l}\text { Orians 1980, Ulrich 1981, Orians \& Heerwagen } \\
1992\end{array}$ \\
\hline $\begin{array}{l}\text { Polootevřená prostranství, umožňující snadný } \\
\text { pohyb }\end{array}$ & $\begin{array}{l}\text { Orians 1980, Ulrich 1981, Orians \& Heerwagen } \\
1992\end{array}$ \\
\hline Mírně zvlněný terén & Orians 1980, Ulrich 1981 \\
\hline Nenarušený výhled na horizont & Orians 1980, Ulrich 1981, Appleton 1975 \\
\hline Zelené rostliny & $\begin{array}{l}\text { Orians 1980, Eibl-Eibesfeldt 1984, Appleton } \\
\text { 1975, Orians \& Heerwagen } 1992\end{array}$ \\
\hline Střední a vyšší komplexita (biodiverzita) & Orians 1980, Ulrich 1981 \\
\hline $\begin{array}{l}\text { Preference } \\
\text { savanového/arkadského/parkového typu }\end{array}$ & $\begin{array}{l}\text { Orians 1980, Balling a Falk } 1982 \text {, Ulrich } 1983, \\
\text { 1986, Orians \& Heerwagen } 1992 \text { atd. (savana } \\
\text { však jen jeden z možných typů!) }\end{array}$ \\
\hline
\end{tabular}




\section{Literatura:}

- $\quad$ Andrews, M. (1999). Landscape and Western Art. Oxford: Oxford University Press.

- $\quad$ Appleton, J. (1975). The Experience of Landscape. London: Wiley.

- Balling, J. D Falk, J. H, (1982). Development of visual preference for natural environments. Environment and Behavior, 14(1), 5-28.

- Barrett, L., Dunbar, R., Lycett, J, (2007). Evoluční psychologie člověka. Praha: Portál.

- Bowlby, J. (1982). Attachment and Loss (3 sv.). New York: Basic Books.

- Caton, H. (2007). Getting our History Right: Six Errors about Darwin and his Influence. Evolutionary Psychology, 5(1), 53-69.

- Coeterier, J. F. . Dominant attributes in the perception and evaluation of the Dutch landscape. Landscape and Urban Planning, 34(1), 27-44.

- Evolutionary Aesthetics (2003). Heidelberg: Springer.

- Eibl-eibesfeldt, I. (1984). Die Biologie des menschlichen Verhalten. München: Piper-Verlag.

- $\quad$ Ehrlich, P. R., Ehrlich, A. H, (1992). The value of biodiversity. Ambio, 21(3), 219-226.

- Ingold, T. (2000). The Poverty of Selectionism. Anthropology Today, ro. Selectionism.anthropology Today, 16(3), 1-2. Retrieved from http://www.blackwellsynergy.com/links/doi/10.1111\%2F1467-8322.00022 http://dx.doi.org/10.1111/1467$\underline{8322.00022}$

- Irons, W. (1998). Adaptively Relevant Environments versus Environment of Evolutionary Adaptedness. Evolutionary Antropology, 6(6), 194-204. Retrieved from http://doi.wiley.com/10.1002/\%28SICI\%2915206505\%281998\%296\%3A6\%3C194\%3A\%3AAID-EVAN2\%3E3.0.CO\%3B2-B http://dx.doi.org/10.1002/(SICI)1520-6505(1998)6:6<194::AID-EVAN2>3.0.CO;2-B

- Kaplan, S. (1987). Aesthetics, affect, and cognition: Environmental preference from an evolutionary perspective. Environment and Behaviour, 19(1), 3-32.

- Kaplan, R., Kaplan, S, (1989). The experience of nature: A psychological prespective. New York: Cambridge University Press.

- Kaplan, S. (1992). The Adapted Mind: Evolutionary Psychology and the Generation of Culture. Oxford: Oxford University Press.

- Koucká, (2006). Láska ke krajině. Psychologie dnes, 11, Retrieved from http://www.portal.cz/scripts/detail.php?id=20556

- LORENTZ, I. von, (1935) Naturgefühl. In Pauly, A., Wissowa, G (Ed.), Paulys RealEnzyklopädie der Classischen Altertumswissenschaft. Stuttgart: J. B. Metzler.

- MacARThUR, R., WILSON, E. O, (1967). The Theory of Island Biogeography. Princeton: Princeton University Press.

- $\quad$ Michel, G. F., \& Moorové, C. L. (1999). Psychobiologie. Praha: Portál.

- Orians, G. H. (1980) Habitat selection: general theory and application to human behavior. In J. S. Lockhard (Ed.), The Evolution of Human Social Behavior(pp. 49-66). New York: Elsevier.

- Panksepp, J., Panksepp, J. B, (2000). The Seven Sins of Evolutionary Psychology. Evolution and Cognition, 6(2), 108-131. 
- Orians, G. H., Heerwagen, J. H, (1992) Evolved Responses to Landscapes. In Barkow, J. H., Cosmides, L., Tooby, J (Ed.), The Adapted Mind. New York: Oxford Press.

- Ruso, B., Renninger, L. A., Atzwanger, K, (2003) Human Habitat Preference: A Generative Territory for Evolutionary Aesthetics Research. In Eckhart, V., Grammer, K (Ed.), Evolutionary Aesthetics (pp. 279-294). Heidelberg: Springer.

- Stella, M., Kleisner, K, (2006) Odvrácená strana umweltu aneb o čem se (ne)mluví. In Kliková, A., Kleisner, K. Umwelt (Ed.), Koncepce žitého světa Jakoba von Uexkülla (pp. 123159). Červený kostelec: Mervart.

- Symons, D. (1989). A critique of darwinian antropology. Ethology and Sociobiology, 10(1-3), 131-144.

- Symons, D. (1990). Adaptiveness and adaptation. Ethology and Sociobiology, 11(4-5), 427444.

- Symons, D. (1992) On the use and misuse of Darwinism in the Study of human behavior. In Barkow, J. H., Cosmides, L., Tooby, J (Ed.), The Adapted Mind: Evolutionary Psychology and the Generation of Culture (pp. 137-162). Oxford: Oxford University Press.

- Syneck, E. (1998). Evolutionary Aesthetics: Visual Complexity and the development of human landscape preferences. Vienna: University of Vienna.

- Summit, J., Sommer, R, (1999). Further Studies of Preferred Tree Shapes. Ecology and Behavior, 31(4), 550-576.

- Cosmides, L., Tooby, J, (1987) From evolution to behavior: evolutionary psychology as the missing link. In J. Dupré (Ed.), The latest on the best: Essays on evolution and optimality (pp. 277-306). Cambridge: MIT Press.

- Uexküll, J. (1920). Theoretische Biologie. Berlin: Springer.

- Ulrich, R. S. (1983) Aesthetic and affective response to natural environment. In Altmann, I., Wohlwill, J. F (Ed.), Behavior and the Natural Environment (pp. 85-125). New York: Plenum.

- Ulrich, R. S. (1986). Human response to vegetation and landscape. Landscape and Urban Planing, 13(1), 29-44. 
Časopis Envigogika vydává Centrum pro otázky životního prostředí UK. Vývoj časopisu je podpořen projektem OP VK Mezioborová sít udržitelného rozvoje.

Více najdete na internetových stránkách projektu mosur.czp.cuni.cz
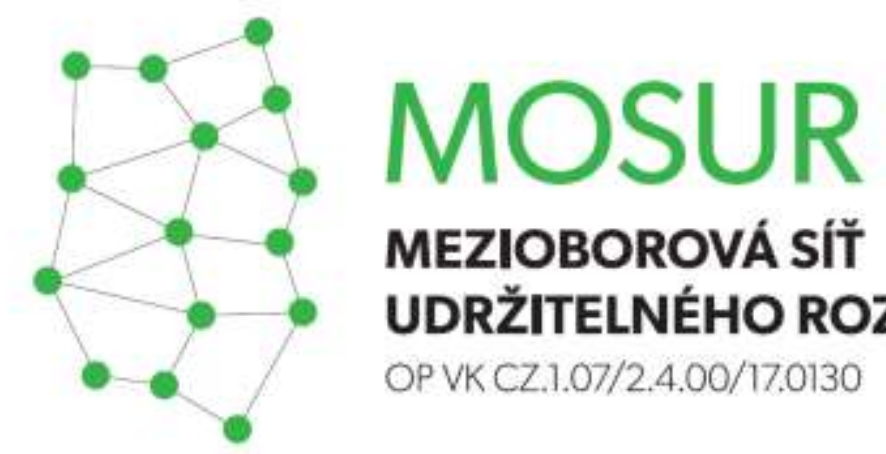

\section{MEZIOBOROVÁ SÍT} UDRŽITELNÉHO ROZVOJE

OP VK CZ.1.07/2.4.00/17.0130
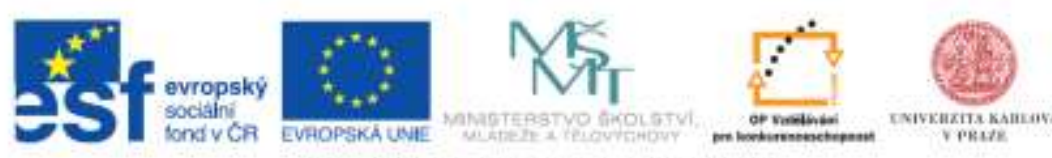

INVESTICE DO ROZVOJE VZDELAVANI 